\title{
The Interleukin-17 Family of Cytokines in Breast Cancer
}

\author{
Joseph Antoine Salvator Fabre 1,2 ${ }^{\mathbb{D}}$, Jérôme Giustiniani ${ }^{3}$, Christian Garbar ${ }^{1,2}$, \\ Yacine Merrouche ${ }^{1,2}$, Frank Antonicelli ${ }^{1,2,+}$ and Armand Bensussan 1,4,5,6,*,† \\ 1 Institut Jean Godinot, Unicancer, F-51726 Reims, France; fabrejoseph@yahoo.fr (J.A.S.F.); \\ Christian.GARBAR@reims.unicancer.fr (C.G.); Yacine.MERROUCHE@reims.unicancer.fr (Y.M.); \\ frank.antonicelli@univ-reims.fr (F.A.) \\ 2 IRMAIC, EA7509, Université Reims-Champagne-Ardenne, 51 rue Cognacq-Jay, 51095 Reims CEDEX, France \\ 3 Institut Mondor de Recherche Biomédicale (INSERM U955), Equipe Immunologie et Oncogenèse des \\ Tumeurs Lymphoïdes, Hôpital Henri Mondor, 94010 Créteil, France; jerome.giustiniani@gmail.com \\ 4 Institut National de la Santé et de la Recherche Médicale (INSERM) U976, Hôpital Saint Louis, \\ 75010 Paris, France \\ 5 Laboratoire Immunologie Dermatologie \& Oncologie, Université Paris Diderot, Sorbonne Paris Cité, \\ UMR-S 976, F-75475 Paris, France \\ 6 OREGA Biotech, 69130 Ecully, France \\ * Correspondence: armand.bensussan@inserm.fr; Tel.: +33-(0)1-49-81-35-13 \\ + These two authors contributed equally.
}

Received: 17 October 2018; Accepted: 28 November 2018; Published: 4 December 2018

\begin{abstract}
Breast cancer (BC) is the most common cancer in women worldwide and remains a major cause of mortality with an expected 137,000 death this year in Europe. Standard management of metastatic BC comprises hormonotherapy, chemotherapy, and targeted therapies. Cyclin dependent kinase (CDK) and mammalian target of rapamycin (mTOR) inhibitors have recently proved their efficiency in hormonal receptor expressing BC. Checkpoint proteins inhibition is being evaluated in phase 3 studies. Since inflammation is constantly present in cancers, research teams have focused their attention on the interleukin-17 (IL-17) family of proinflammatory cytokines. Preclinical experiments have reported both pro and antitumor effects depending on the conditions. In the present article, we review the accumulating evidences about the roles of IL-17 in BC and discuss whether this family of cytokines could be a new target in anticancer treatments.
\end{abstract}

Keywords: interleukin-17; breast cancer; protumor effects; antitumor effects; new target; immunotherapy

\section{Introduction}

In 2018, breast cancer (BC) remains a burden for women all around the world. Considering Europe only, female BC represents 523,000 cases, standing as the first cause of cancer before the 500,000 cases of colon cancer [1]. BC management has evolved tremendously over these last 30 years. Risk factors are better understood but efficient prevention means are to be found yet. Improvement in patients screening and diagnosis has led to a drop of BC mortality. By using mammography, physicians are able to detect $\mathrm{BC}$ at the earliest stages, which helps allowing curability and reduce the mortality effectively [2]. This is especially true for localized BC, which can be cured in more than $80 \%$ patients [2]. Unfortunately, patient with aggressive and extended disease only survive between 3 and 12 months for most of them in the latest trials [3]. Late stages, like metastatic breast cancer, allow palliative systemic treatments only, such as chemotherapy and targeted therapies most of the time [4].

Decision-making is based on clinical assessment of the patient, tumor staging, but also on the immunohistochemical characteristics of the disease [2]. Among the 20 different histological subtypes 
of BC, the most frequent are the Invasive Carcinoma of No Special Type (IC-NST) and the Invasive Lobular Carcinoma (ILC) representing around $80 \%$ and $5-15 \%$ of all cases, respectively [2]. Assessing the presence of biomarkers, such as estrogen receptors (ER), progesterone receptors (PR), human epidermal growth factor 2 (HER2), and determining the proliferative index Ki67 helps defining BC subtypes, each having a different response to endocrine therapy, chemotherapy or HER2 targeted treatment such as trastuzumab [5]. Besides, groundbreaking studies of the gene expression patterns by Perou and Sorlie identified two main clusters relevant for their clinical behavior and outcome $[6,7]$. The largest cluster is ER-positive tumors and comprises Luminal A and B subtypes [8]. Luminal A BC are positive for ER and PR, negative for HER2, have a low Ki67 and P53 mutations rate, whereas Luminal B can either bear HER2 overexpression or not, have a lower expression of hormonal receptors but still positive, a higher rate of p53 mutations and a high expression of proliferation related genes [8]. HER2+ tumors overexpress HER2, but are negative for hormonal receptors detection [8]. Basal-like tumors present as triple negative for ER, PR and HER2 by immunohistochemistry staining, have the highest rate of p53 mutations, and express cytokeratins and proliferation genes [8].

Better understanding of molecular and genetic diversity of BC leads the path to personalized treatments [7]. Most recent anticancer treatments build up on biological mechanisms. Thus, favoring the molecular stratification of $B C$ is now required to manage patient appropriately [9]. Treatments of patients with a disseminated disease rest on the combination of systemic intravenous therapies like endocrine therapy, chemotherapy, monoclonal antibodies, tyrosine kinase inhibitors (TKI) or polyadenosine phosphate ribose polymerase (PARP) inhibitors [9]. Recently cyclin-dependent kinases and mammalian target of rapamycin inhibitors have proved their efficiency in hormonal receptor expressing BC [10]. Unlike patients with an early disease, chance of cure in a metastatic setting are very poor because $\mathrm{BC}$ cells either inevitably develop resistance to every single agent or find shelter in organs like brain or bones, where chemotherapy does not penetrate well enough [10]. Treatments then are more likely to be evaluated in terms of progression free survival [11]. A retrospective study from SEER registries on 25,323 women diagnosed with a stage IV BC reported overall survival (OS) at 5 years and 10 years of only $26.8 \%$ and $12.8 \%$, respectively [12]. If overall response rate remain low in immunotherapy (about 20\%) [13], combination with chemotherapy may bring higher rates [14].

Considering cancer is frequently associated and enhanced by local inflammation, research teams have been investigating the tumor microenvironment with success [15]. Breakthrough results have been obtained with checkpoint inhibition in melanoma or nonsmall cells lung cancers (NSCLC) [16,17]. In order to improve long-term survival, recent trial in $\mathrm{BC}$ are also investigating checkpoint inhibitor-based immunotherapy and provide promising results especially in triple negative breast cancer (TNBC), where inflammation is preponderant, although HER2+ tumors may also be concerned (Figure 1). First results in BC presented at the 2018 American Society of Oncology meeting are promising but good, long-term outcomes only concern a minority of patients [18]. Nevertheless, those positive results remain insufficient since only a minority of patients will benefit from it, and new treatment targets are desperately needed.

Virchow considered a relationship between inflammation and cancer early in 1863 [19]. Cancer at several stages of its development is known to be regulated by inflammation that recruits resident or circulating immune cells to modulate the tumor microenvironment [20]. These reactions are orchestrated by soluble mediators also called cytokines, secreted either by the host immune system, or by malignant cells [21]. Several interleukins have already been used as treatment or therapeutic target in oncology. IL-2 as well as IL-21, for instance have been tested in clinical trials in Melanoma and renal cell carcinoma [22]. In breast cancer, several studies have evaluated the functions of IL-1, IL-6, IL-17, IL-32 families of cytokine [23-25]. In the present work, we focus on the IL-17 family of cytokines. The interleukin-17 (IL-17) family of cytokines is deeply implicated in chronic inflammatory diseases and is gaining interest as an actor in cancer immunity [26]. Targeting the IL-17/IL-17R axis in breast cancer preclinical models seems to produce versatile effects depending on the manner the studies are conducted [27] (Table 1). In first place, we recall the fundamental knowledge of the IL-17/IL-17R 
axis, then we review the accumulating evidence about the role of IL-17 in BC, and finally we discuss whether it could be used as a therapeutic target in clinical practice.

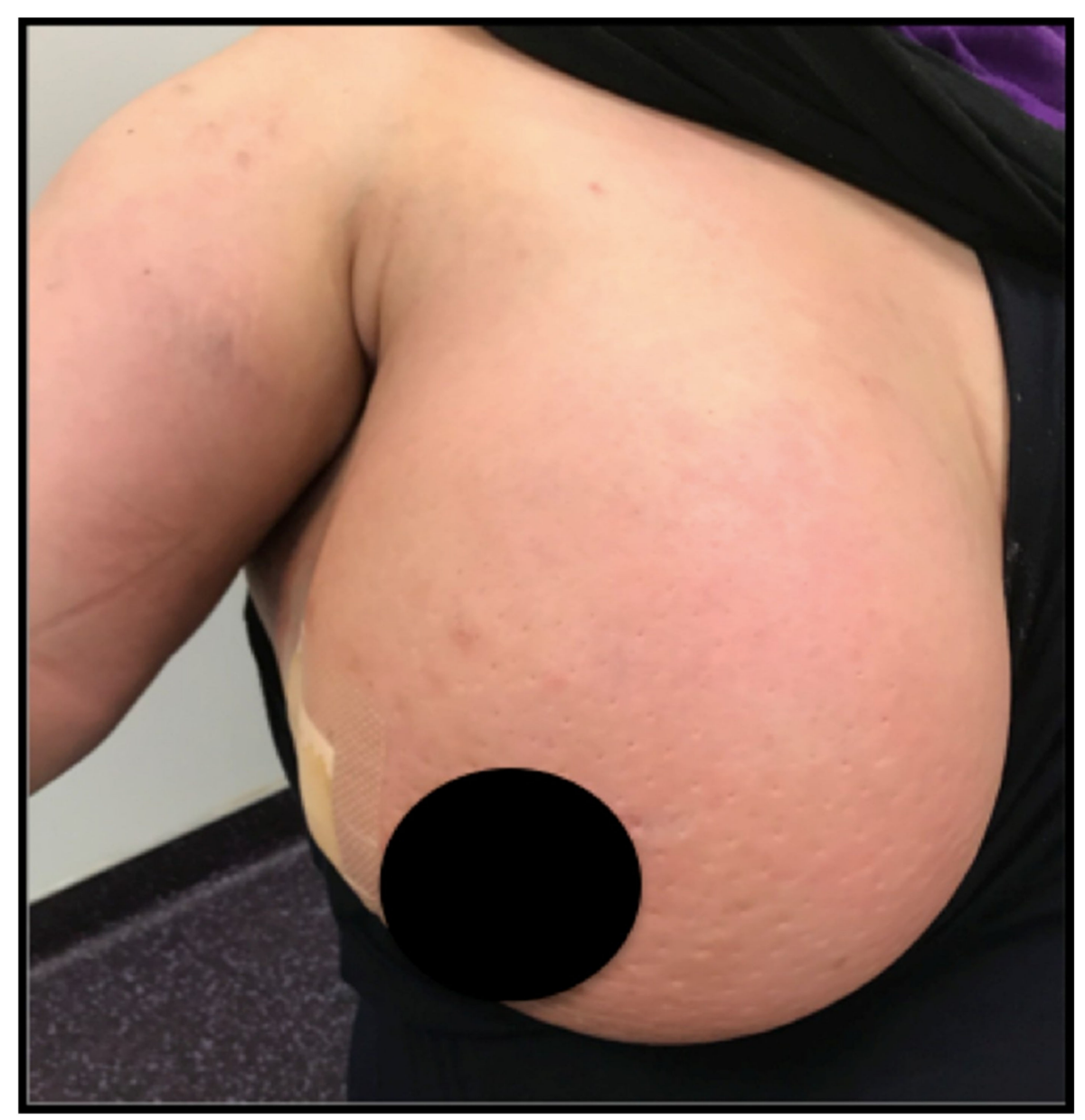

Figure 1. Photograph of an inflammatory breast cancer case with typical "orange skin".

\section{The IL-17/IL-17R Axis}

\subsection{The Interleukin-17 Family of Cytokine}

Firstly discovered and prototypic member of the family, IL-17A also called IL-17 was initially named CTLA8 by Rouvier et al. in 1993 [28]. It was highlighted while screening a lymphoid cell gene expression library in quest for novel immune molecules. The mRNA sequence of CTLA 8 had homologies with other cytokines like a $3^{\prime}$ untranslated region adenylate-uridylate-rich (AUR) elements and a hydrophobic N-terminal sequence [28]. Two years later, Yao et al. determined that CTLA8 could upregulate NF-kB and trigger IL-6 secretion in fibroblasts, and provoke T cell proliferation [29]. They also isolated a cDNA encoding for an unknown receptor that could bind CTLA8, and proposed to name them IL-17R and IL-17 respectively [29]. With the human genome sequencing achieved, 5 other members of the IL-17 family, IL-17B, IL-17C, IL-17D, IL-17E and IL-17F were recognized using sequence homology [30]. These cytokines play roles in immunity, in infections [31], in tumor immunity [32], in inflammatory chronic disease [33,34], in autoimmunity [35-37], and in atherosclerosis [38]. IL-17F is the closest to IL-17A from a sequence point of view ( $55 \%$ homology), is secreted by the same cell types and the genes encoding these two cytokines are both located on chromosome 6 [39]. IL-17F had its crystal structure determined first, which revealed a monomer fold typical of cysteine knot growth factors, such as Nerve growth Factors [40]. This structural motif is shared among all members of the family and is also present in bone morphogenic proteins (BMPs), transforming growth factor $\beta$ (TGF- $\beta$ ) 
and platelet-derived growth factor BB (PDGF-BB) [41,42]. IL-17A and IL-17F can be secreted either as homodimers or as a heterodimer cytokine typed IL-17A/F [43,44]. Oppositely, IL-17E, also called IL-25, shares the lowest rate (17\%) of similarity with IL-17A [45], compared with IL-17B (29\%), IL-17D (25\%), and IL-17C (23\%) [46,47]. IL-17A and IL-17F are the hallmark of Th17 lymphocytes production, but not only [36], conversely to IL-17B, IL-17C, IL-17D and IL-17E, which are expressed by diverse cellular sources [48].

\subsection{The Interleukin-17 Receptor}

Every member of the IL-17 family signals through a specific family of receptors named interleukin-17 receptors (IL-17R) [42]. The functional receptor is a heterodimer composed by the association of 2 among the 5 different subunits (IL-17RA to IL-17RE) identified so far, each presenting as a single-pass transmembrane protein. All subunits have in common an extracellular fibronectin III domains and an intracellular "SEFIR" (similar expression to fibroblast growth factor genes and IL-17R) domain. A helix $\alpha \mathrm{C}$ motif inside the SEFIR domain appears to be mandatory for interactions with Act1 [49]. Subunits combinations are specific of the IL-17 type they can match with. IL-17A, IL-17F and IL-17A/F dock to IL-17RA/RC, IL-17B and E involve IL-17RB subunit, IL-17C signals through IL-17RA/RE [50,51]. These evidences point out IL-17RA as a major partner. The receptor for IL-17D and the ligand for IL-17RD are yet to bet discovered. Signaling pathways differ between heterodimers, and they have different affinity according to the type of cytokines they bind to. IL-17F has the lowest affinity with IL-17RA and the highest affinity with IL-17RC, but IL-17A signaling produces more potent effects than IL-17F [52,53]. Two different pathways can be activated when IL-17RA/RC recognizes IL-17A. The canonical pathway activates Act1 via the SEFIR domain, which leads to E3 ligase activation and ubiquitination of TRAF6. Follows the activation of NF-kB and MAPK pathways, including ERK, p38 and JNK. This ultimately leads to the transcription of the genes of the inflammatory response. The noncanonical pathway is mediated by IkB kinase (IKKi) and the phosphorylation of Act 1 at residue 311 by TBK1. The receptor complex then recruits TRAF2 and TRAF5. Then, mRNA stabilizing molecules are activated such as HuR and in parallel destabilizing factors such as ASF/SF2 are inhibited [54]. Other IL-17 receptors have been reported to recruit intracellular effectors TRAF4, TRAF6-TAK1 complex, SMURF2, DAZAP2 in different organs and settings.

\subsection{Cellular Production of IL-17}

Initially, Thelpers were thought to differentiate into only two subtypes, Th1 and Th2, tough the possibility of the existence of other subtypes was considered [55]. Besides, IL-17 production could be obtained from some Th0 or Th1 clones from synovial membranes and synovial fluids of rheumatoid arthritis patients but not from Th2 lymphocytes [56]. Indeed, the scientific community, because of the discordance they observed, rapidly questioned this model [57]. In 2005, Park et al. were the first to discover a third lineage of Th cell, which could produce IL-17A [58]. Further studies indicated that these "Th17" lymphocytes could also secrete IL-17F as well as IL-21, IL-22 and GM-CSF [59-61]. Commitment to the Th17 pathway is a two-step process. First naïve T cells (Th0) have to be activated by dendritic cells concomitantly to, IL-6 and TGF- $\beta$ (or IL-1 $\beta$, IL-6 and IL-23) exposure. Thus IL-23R gene becomes upregulated [62]. Then, IL-23 needs to be present to stimulate IL-23R, and to launch intracellular signal through STAT3 and TYK3 in order to reveal full aptness [63]. Lymphocyte Th17 polarization following cytokine immersion takes place in secondary lymphoid organs, during antigens presentation [64]. Similarly to Th1 and Th2 lymphocytes, activated Th17 recruit a signature transcription factor named RAR-related orphan receptor gamma (ROR $\gamma$ ) responsible for the transcription of several specific DNA loci critical for Th17 differentiation [65].

Recent reports strongly support secretion of IL-17A and IL-17F by other cellular sources than Th17. Huber et al. observed CD8+ T cytotoxic cells could be an important source of IL-17A [66]. Innate tissue resident cells (ITRC) have also been reported to participate to IL-17 production [38]. This last subset comprises $\gamma \delta$ T cells, type 3 innate lymphoid cells (ILC3), NKT cells and "natural" 
Th17 $[67,68]$. These cells are posted at barrier sites and can respond quickly to germs and tissue aggression with IL-17 synthesis [69]. Biologically, they harbor the chemokine receptor CCR6 and rely upon IL-23 exposure and ROR $\gamma$ activation to produce IL-17. IL-17 production was also associated with infiltrated innate immune cells. Actually, IL-17 production has been mainly attributed to neutrophils in bullous pemphigoid, a skin autoimmune bullous disease [36]. Possibility of IL-17A expression by macrophages, and mast cells remains under discussion. Phagocytosis mechanism probably explains why IL-17 in these myeloid cells is measured at levels significantly below than those detected in Th17 cells. Some authors even observed mast cells could engulf extracellular IL-17A from the environment via receptor-mediated endocytosis, store it, and release it during tissue inflammation [70]. In addition, IL-17A can be liberated as extracellular traps by either neutrophils or mast cells [71].

IL-17E has at least $80 \%$ of divergence with IL-17A, B and C and can be produced by hematopoietic and nonhematopoietic cells [72]. The expression of IL-17E by mast cells and alveolar macrophages has been observed in a mice model of asthma [73]. In humans, detection of IL-17E mRNA was detected in eosinophils and basophils of allergic subjects [74]. Still in the context of infection or allergy, expression of IL-17E is also possible by tissue stromal cells like lung epithelial cells and murine primary type II alveolar epithelial cells [75]. Thus, in asthmatics, concentrations of IL-17E were significantly enhanced in the bronchial mucosa and dermis when challenged by antigen. Noteworthy, in this study, endothelial cells were also positive for IL-17E immunoreactivity [76]. These results show that IL-17E-induced inflammation is pleiotropic and characterized mostly by an eosinophil infiltrate, whereas IL-17A and IL-17F production rather involve neutrophils. Besides, this study confirms deep implication in the deregulation of Th2 responses seen in chronic allergy diseases [77].

IL-17C is less known than IL-17A, IL-17F and IL-17E, and its roles in inflammation or infection are only beginning to be understood. It has the particularity to be secreted by epithelial cells I in response to toll like receptor 2 (TLR2) and TLR5 ligand binding and stimulation by IL-1 $\beta$ and TNF- $\alpha$ [78]. Additional cell types comprising CD4+ T lymphocytes, dendritic cells and macrophages have been reported to be sources of IL-17C, though at lesser levels [79,80].

IL-17B seems pleiotropic, and has been detected in various cell types such as neurons, intestinal epithelial cells chondrocytes, and BC cells [80]. Finally, IL-17D can be expressed in various organs comprising adipose tissue, brain, heart, lung pancreas and skeletal muscle, and seems to be limited to naïve CD4+ T cells and B cells [81].

\section{Roles of IL-17 in Breast Cancer Models}

It is now well known that tumor cell detour the inflammatory process to progress, metastasize and evade destruction by immune cells [82]. Inhibitors of IL-17/IL-17R have been quite successful in inflammatory diseases, especially in psoriasis where tremendous responses in advanced disease and a real benefit for patients were obtained [83]. Breast cancer presents clinically under an inflammatory form (Figure 1) in 5\% of cases and some subtypes such as TNBC or HER2+ are known to heavily rely on inflammation [84]. Therefore, researchers first tried to detect IL-17 family members' expression in the tumor environment.

In a both preclinical and clinical study, Zhu et al. examined tissue material from 4 Scarf Bloom and Richardson (SBR) grade II and 15 SBR III tumors (molecular subtype was not mentioned) [85]. Peritumoral area was strongly stained for IL-17 in 8 of the grade III lesions but none of the grade II [85]. Regarding the identity of the IL-17+ cells, they corresponded to CD68+ macrophages [85]. Notably, no staining was observed on the BC cells [85]. When assessing the impact of IL-17 on BC cell lines (Luminal A MCF-7 and T47D, triple negative MDA-MB435 and MDA-MB231), they observed that metalloproteinase (MMP)-dependent invasion of matrigel was increased in MDA-435 and MDA-MB231, but not on the other cell lines when supplemented with IL-17 [85]. Several other studies support a protumor role of IL-17 in BC and are listed in Table 1 [45,86-92]. In a murine model grafted with TNBC, Du et al. observed that intratumoral level of IL-17 was increased and correlated with the expansion of the disease [87]. They also assessed the impact of IL-17 on the TNBC grafts and 
reported a stimulatory effect on growth and on angiogenesis with microvascular density [87]. Another report indicated that IL-17 promoted tumor graft development and directly inhibited apoptosis in 4T1, MDA-MB-231 and EM6 BC cell lines in a TGF- $\beta$ dependent manner [90]. Further, it is shown that this effect was reversible under IL-17R suppression using knock out technique [90]. Stimulation of MCF7 BC cells by IL-17A induced MEK, ERK, JNK, cJun and STAT3 phosphorylation and lead to increased cell proliferation as assessed with BrdU incorporation [35]. Concordantly, tyrosine kinase inhibitors drastically reduced colony formation, and even abolished it completely in siRNA-IL-17A cells. The author hypothesized that MAPK activation was initiated by recruiting tumor progression locus 2 (TPL2), but they could only observe it on epidermal cells [35]. Our team has been investigating IL-17 role in breast cancer for several years $[86,89,93,94])$. We demonstrated that tumor infiltrated lymphocytes (TIL) isolated from BC biopsies secreted pathophysiological IL-17A. Consistent with Nam et al., we demonstrated that recombinant IL-17A activated the ERK1/2 pathway and thus promoted resistance to docetaxel-based chemotherapy in various cell lines [86]. Proliferation of ER+ T47D cells was significantly enhanced as well as migration and invasion of MCF7. Besides, physiological IL-17A had the same proliferative and protective effects as recombinants, which were partially abrogated by anti-IL-17A OREG-203 antibody [86]. We then dug deeper in the signaling pathway and reported that the recruitment of c-RAF and S6 kinases by both IL-17A and IL-17E, confers chemoresistance and to ultimately generates low molecular weight cyclin E [93], which is clinically associated with poor prognosis [95]. A well-known mechanism of chemoresistance and/or radioresistance is the recruitment of members of the epidermal growth factor (EGF) family (HER) of receptors [96]. We reported in 2016 that IL-17 signaling probably had crosslinks with HER1 [89]. Indeed, stimulation of TNBC cell lines with IL-17E induced the phosphorylation of HER1 and triggered pHER1 and pSTAT3 translocation to the nucleus, and promoted resistance to TKI [89]. Noteworthy, this mechanism was abolished by anti-IL-17RB antibodies [89]. IL-17B has also shown protumor roles in BC. Huang et al. observed that activation of IL-17B/IL-17RB signaling had protumor effects in vitro and in vivo via TRAF6 and NF-kB [97]. Conversely, in our last study, IL-17B produced IL-17RB-mediated resistance to paclitaxel in cell lines BT20, MDA-MB-468 and MCF7 [94]. Similar findings were obtained in vivo, in an experimental model of xenografted nude mice [94]. Subcutaneously injected IL-17RB or MAPK antibodies inhibited cell resistance to chemotherapy [94]. Meanwhile, IL-17B did not affect cell or tumor proliferation [94]. Apart from the direct effects on BC cells, an indirect role of IL-17 on neutrophils has been reported by Coffelt et al. [98]. In mice, the authors observed that $\gamma \delta \mathrm{T}$ cells were the main source of IL-17A, which release induced neutrophils to suppress CD8+ T lymphocytes, and subsequently metastases development [99]. Depletion of neutrophils or $\gamma \delta \mathrm{T}$ cells did not affect the primary tumor progression, but significantly reduced pulmonary and lymph node metastasis [99]. Besides neutrophils, tumor-infiltrated Th2 cells and macrophages may be affected by IL-17 cytokines as described in [99]. IL-17E was expressed by tumor infiltrating CD4+ T cells and macrophages, and inhibition of IL-17E caused reduced tumor infiltration by both types of leucocytes, which was associated with a significantly disabled lung metastasis formation [99]. Some authors proposed that the IL-17A positive impact on metastasis rate was related to its effects on MMP-11 upregulation in mononuclear inflammatory cells [88,100]. Concordantly, Roy et al. reported in a pro arthritic mouse model that IL-17A induced metastases to the bones and lungs via upregulation of stromal cell derived factor 1 (SDF-1) directly or via IL-6 and M-CSF secretion promotion [91,92].

In opposition, research teams have shown in certain conditions anti-tumor effects of IL-17 [101-103]. In cancer xenograft mouse models (CD1 nude and SCID), a variety of tumors (melanoma, nonsmall cell lung cancer, colon adenocarcinoma, pancreatic adenocarcinoma and breast adenocarcinoma) were analyzed with respect to IL-17 expression [101]. Human IL-17E (hIL-17E) or mouse IL-17E (mIL-17E) was administered using different routes [101]. Every cancer type including BC cell lines MDA-MB-435 was reported to have significantly reduced size upon IL-17E stimulation as compared with control. Besides, antitumor activity of IL-17E was potentiated when combined with cisplatin or taxol [101]. This effect was nullified in T and B cells deficient mice but not in those lacking 
only T lymphocytes suggesting a critical role of B lymphocyte in the antitumor effect of IL-17E [101]. Furuta et al. identified IL-17E as responsible for the cytotoxicity they observed when adding the conditioned medium (CM) from nonmalignant mammary epithelial cell (MEC) to breast cancer cell cultures [102]. Indeed, when they cultured BC cell lines with purified IL-17E from MEC, or injected it in murine model of $\mathrm{BC}$ grafts, they obtained respectively a drop in the number and size of the colonies, and a strong antitumor effect [102]. Recent study by Ma et al. added that IL-17A could directly induce myeloid-derived suppressor cell lines differentiation, apoptosis and reduced proliferation indicating that enhancing IL-17 pathway may revive immune response [103].

Table 1. Studies reporting the roles of IL-17 cytokines in breast cancer in vitro and/or in vivo.

\begin{tabular}{|c|c|c|c|c|c|c|}
\hline $\begin{array}{l}\text { Type of } \\
\text { IL-17 }\end{array}$ & $\begin{array}{l}\text { Type of } \\
\text { Study }\end{array}$ & $\begin{array}{l}\text { Breast Cancer } \\
\text { Cell Lines }\end{array}$ & $\begin{array}{l}\text { Effect of IL-17 } \\
\text { Exposure }\end{array}$ & Murine Model & Mechanism & Reference \\
\hline IL-17A & $\begin{array}{l}\text { Clinical and } \\
\text { preclinical }\end{array}$ & No & Anti & BALB/c Nude & $\begin{array}{c}\text { Induction of differentiation } \\
\text { and apoptosis, inhibition of } \\
\text { proliferation of } \\
\text { MDSC via STAT3 }\end{array}$ & [103] \\
\hline IL-17A & Preclinical & No & Pro & KEP, Tcr $\delta-/-$ & $\begin{array}{l}\text { Production of IL-17A by } \gamma \delta \mathrm{T} \\
\text { cells induces neutrophils to } \\
\text { suppress CD8+ T Cells and } \\
\text { promotes distant metastases. }\end{array}$ & [98] \\
\hline IL-17A & $\begin{array}{l}\text { Clinical and } \\
\text { preclinical }\end{array}$ & $\begin{array}{c}\text { MCF7, T47D, } \\
\text { BT20, } \\
\text { MDA-MB468, } \\
\text { MD-MB157, } \\
\text { MDA-MB231 }\end{array}$ & Pro & No & $\begin{array}{c}\text { Activation or ERK1/2 } \\
\text { pathway induces } \\
\text { proliferation, migration, } \\
\text { invasion and chemoresistance }\end{array}$ & [86] \\
\hline IL-17A & Clinical & No & Pro & No & $\begin{array}{l}\text { IL-17A associated to } \\
\text { MMP-11+ mononuclear } \\
\text { infiltrating cells which are } \\
\text { correlated to metastasis }\end{array}$ & {$[88,100]$} \\
\hline IL-17A & Preclinical & MCF7 & Pro & No & $\begin{array}{l}\text { Activation of MAPK: MEKK, } \\
\text { ERK, JNK, cJun, STAT3.Cell } \\
\text { proliferation. }\end{array}$ & [35] \\
\hline IL-17A & Preclinical & MA782, 4T1 & Pro & $\mathrm{BALB} / \mathrm{c}$ & $\begin{array}{l}\text { Increase in tumor volume } \\
\text { and microvascular density }\end{array}$ & [87] \\
\hline IL-17A & Preclinical & $\begin{array}{l}\text { 4T1, PyV MT } \\
\text { cell line }\end{array}$ & Pro & $\begin{array}{c}\text { PyV MT, } \\
\text { arthritic PyV MT }\end{array}$ & $\begin{array}{l}\text { Upregulation of SDF1, IL-6, } \\
\text { G-CSF. Promotion of bone } \\
\text { and lung metastases }\end{array}$ & {$[91,92]$} \\
\hline IL-17A & $\begin{array}{l}\text { Clinical and } \\
\text { preclinical }\end{array}$ & $\begin{array}{l}\text { MCF-7, T47D, } \\
\text { MDA-MB435, } \\
\text { MDA-MB231 }\end{array}$ & Pro & No & $\begin{array}{l}\text { Recruitment of macrophages, } \\
\text { activation of MMP }\end{array}$ & [85] \\
\hline IL-17A & Preclinical & $\begin{array}{c}\text { 4T1, } \\
\text { MDA-MB231, } \\
\text { EM6, } \\
\text { MDA-MB435, } \\
\text { Hs578t }\end{array}$ & Pro & $\mathrm{BALB} / \mathrm{c}$ & $\begin{array}{l}\text { TGF- } \beta \text { dependent tumor } \\
\text { growth, inhibition } \\
\text { of apoptosis }\end{array}$ & [104] \\
\hline IL-17E & $\begin{array}{l}\text { Clinical and } \\
\text { preclinical }\end{array}$ & No & Pro & MMTV-PyMT & $\begin{array}{c}\text { Production of IL-17E by } \\
\text { tumor- infiltrating } \\
\text { macrophages }\end{array}$ & [99] \\
\hline IL-17E & Preclinical & $\begin{array}{c}\text { MCF7, } \\
\text { MDA-MB468, } \\
\text { MDA-MB 435-S, } \\
\text { MDA-MB231,SKBR3, } \\
\text { T47D, ZR75, } \\
\text { Hs578t, } \\
\text { HCC1937, } \\
\text { MDA-MB175-7 }\end{array}$ & 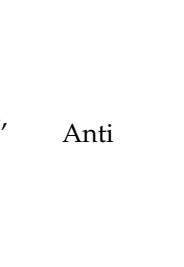 & Nude & $\begin{array}{l}\text { Induction of apoptosis, } \\
\text { decrease in colony formation } \\
\text { and tumor growth }\end{array}$ & [102] \\
\hline IL-17E & Preclinical & MDA-MB-435 & Anti & CD1-nude & $\begin{array}{l}\text { Decrease in tumor volume. } \\
\text { B cells mandatory }\end{array}$ & [101] \\
\hline $\begin{array}{l}\text { IL-17A } \\
\text { and } \\
\text { Il-17E }\end{array}$ & Preclinical & $\begin{array}{l}\text { MDA-MB468, } \\
\text { BT20, IJG-1731 }\end{array}$ & Pro & No & $\begin{array}{l}\text { Activation of STAT3, PYK-2, } \\
\text { Src and HER-1. Nuclear } \\
\text { translocation of pSTAT3 and } \\
\text { pHER-1. Resistance to TKI. }\end{array}$ & [89] \\
\hline
\end{tabular}


Table 1. Cont.

\begin{tabular}{|c|c|c|c|c|c|c|}
\hline $\begin{array}{c}\text { Type of } \\
\text { IL-17 }\end{array}$ & $\begin{array}{l}\text { Type of } \\
\text { Study }\end{array}$ & $\begin{array}{c}\text { Breast Cancer } \\
\text { Cell Lines }\end{array}$ & $\begin{array}{c}\text { Effect of IL-17 } \\
\text { Exposure }\end{array}$ & Murine Model & Mechanism & Reference \\
\hline $\begin{array}{l}\text { IL-17A } \\
\text { and } \\
\text { IL-17E }\end{array}$ & $\begin{array}{c}\text { Clinical and } \\
\text { preclinical }\end{array}$ & $\begin{array}{r}\text { T47D, MCF7, } \\
\text { BT20, IJG-1731 }\end{array}$ & Pro & No & $\begin{array}{l}\text { Activation of cRAF and S6 } \\
\text { kinases. Chemoresistance } \\
\text { and generation of LMWCE }\end{array}$ & [93] \\
\hline IL-17B & $\begin{array}{c}\text { Clinical and } \\
\text { preclinical }\end{array}$ & $\begin{array}{l}\text { BT20, } \\
\text { MDA-MB-468, } \\
\text { MCF7 }\end{array}$ & Pro & Nude & $\begin{array}{c}\text { Resistance to paclitaxel in cell } \\
\text { lines and xenografts } \\
\text { via ERK pathway. } \\
\text { Upregulation of BCL2. }\end{array}$ & [94] \\
\hline IL-17B & $\begin{array}{c}\text { Clinical and } \\
\text { preclinical }\end{array}$ & $\begin{array}{c}\text { MCF7, } \\
\text { MDA-MB-157, } \\
\text { MDA-MB-231, } \\
\text { MDA-MB-361, } \\
\text { MDA-MB-468, } \\
\text { SKBR3, } \\
\text { SKBR3-hr }\end{array}$ & Pro & $\mathrm{NOD} / \mathrm{SCID} / \gamma^{\text {null }}$ & $\begin{array}{c}\text { Promotion of proliferation } \\
\text { and tumor growth through } \\
\text { IL-17RB via } \\
\text { NF-kB and TRAF6 }\end{array}$ & [97] \\
\hline
\end{tabular}

\section{Discussion}

From its discovery to now, the IL-17 family of cytokines has revealed critical roles in inflammatory disease and seems deeply implicated in cancer development [105]. Here, we synthetized the results of studies published to date about the roles of the IL-17 family cytokines in BC cells. Of the 6 members, only IL-17A, IL-17B and IL-17E were reported to have oncogenic effects (Figure 2). Protumoral effects on proliferation, angiogenesis, invasion, migration and resistance to treatments have been observed in a variety of cell lines and mouse models. These effects may be direct via widely detected IL-17Rs signaling through MAPK and NF-kB recruitment. IL-17 cytokines also act indirectly on immune and nonimmune peritumoral cells' cytokine secretion. In certain conditions, an antitumor role was also described. The same duality has been observed in other tumor types making IL-17 a "double-edged sword" in oncology [106]. Honorati et al. for instance, described improved susceptibility of U-2 osteosarcoma to NK cell lysing ex vivo [107]. This observation concurs with the anti-tumor effects on sarcoma of IL-17D in vivo via NK cells recruitment [108]. In opposition, IL-17A has been reported to promote tumor growth either indirectly via the production of other pro inflammatory cytokines by immune cells, or directly via stimulation of tumor stem cells in glioma models [109]. Protumor effects of IL-17 seem also preeminent in cervical and lung cancer using different action modes [110]. From a cellular point of view, IL-17A promoted invasion and migration, [111] potentially via MMP expression through p38/NF-kB pathway activation [112]. In vivo, experiments are converging towards tumor growth stimulating roles [113] possibly through angiogenesis stimulation by VEGF [114]. Nevertheless, cancer types investigated in these studies have far different behavior than BC. Prostate cancer $(\operatorname{PrC})$ on the other hand, share numerous similarities with $\mathrm{BC}$, in particular a vast diversity of phenotypes, biology and both cancer types build on steroidal stimulation to develop and expand [115]. Zhang et al. observed that IL-17A could promote prostate adenocarcinoma formation and development in mice models [116], and later suggested the MMP-7-induced epithelial-to-mesenchymal transition as a possible mechanism induced by IL-17A [117]. The same team also reported in a model that IL-17A in combination with insulin/IGF1 enhanced VCAM-1 increased the expression of endothelial cells and thus increased PrC cells adhesion [118].

Overall, conflicting outcomes may simply result of different experimental conditions and variation of the environment. Timing of BC cells exposure to IL-17, type of cells present, and stage of the disease may also be of importance [119]. Nevertheless, data converge to present IL-17/IL-17R signaling as a potential target especially in inflammatory forms of $\mathrm{BC}$, embodied by triple negative and Her2+ subtypes. Besides, from the now consequent experiences in psoriasis, IL-17 pathway disrupting antibodies such as secukinumab, ixekizumab, ustekinumab and brodalumab have proven to be safe to use [120]. Therefore, we look forward to developing strategies integrating the cytokines of the IL-17 family in anticancer therapies. 


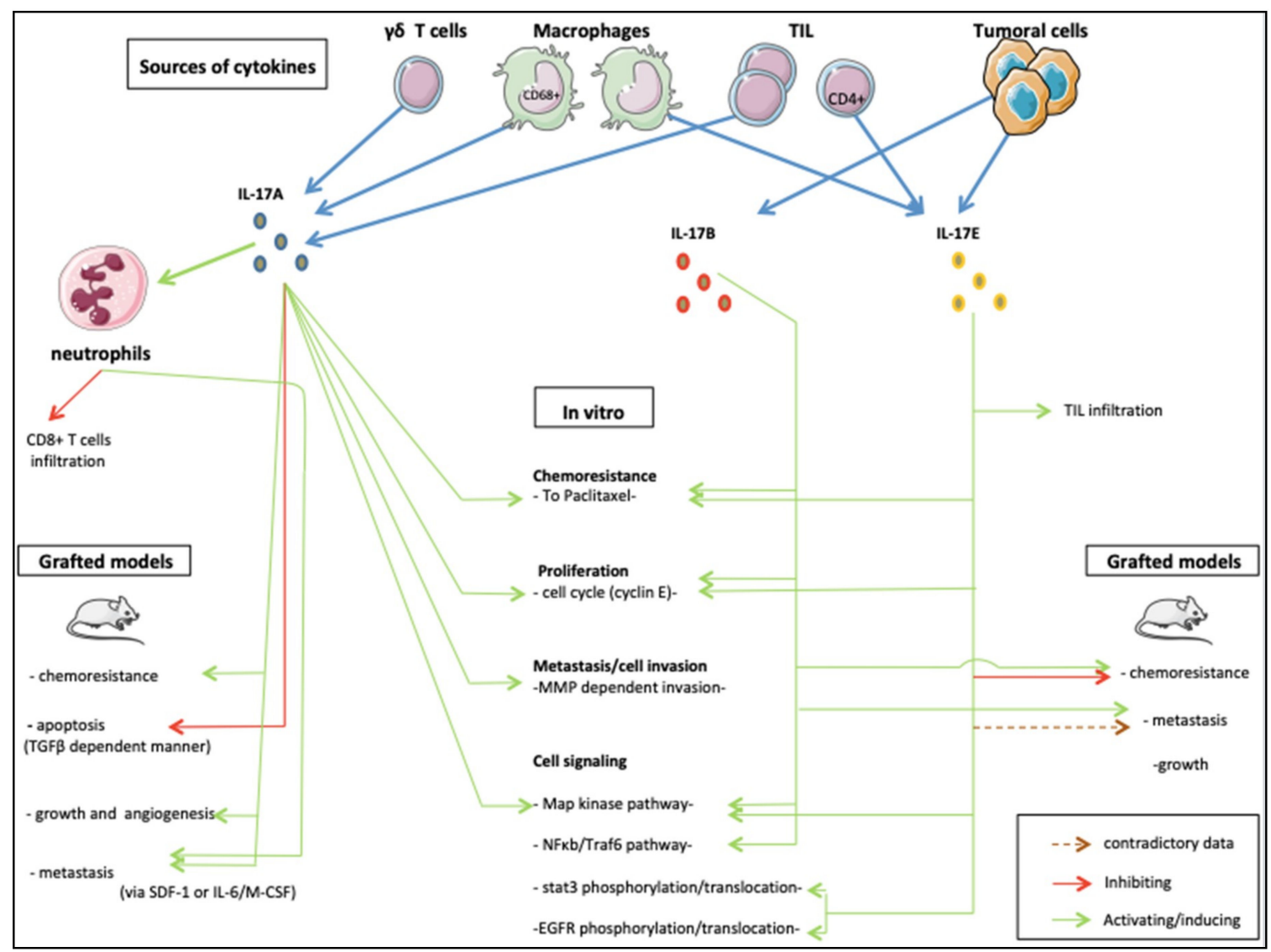

Figure 2. The roles of IL-17 family members in breast cancer.

\section{Patents}

The authors own possession of the photograph in Figure 1 and have informed consent of the patient.

Combinations therapies for treatment of cancer. WO2017194554.

Funding: This research received no external funding.

Conflicts of Interest: Armand Bensussan is co-founder and shareholder of OREGA-Biotech. Armand Bensussan, Jérôme Giustiniani, Christian Garbar, Yacine Merrouche hold certain intellectual property rights related to IL-17 patents. Joseph Antoine Salvator Fabre and Frank Antonicelli declare no conflict of interest.

\section{Abbreviations}

$\mathrm{BC}$

Breast cancer

CDK Cyclin dependent kinase

mTOR Mammalian target of rapamycin

IL Interleukin

NSCLC Nonsquamous cells lung cancer

IC-NST Invasive carcinoma of non special type

ILC Invasive lobular carcinoma

ER Estrogen receptor

PR Progesterone receptor

HER Human epidermal growth factor receptor

TKI Tyrosine kinase inhibitors

PARP Poly adenosine diphosphate ribose polymerase

SEER Surveillance epidemiology and end results 
TNBC Triple negative breast cancer

OS Overall survival

CTLA8 Cytotoxic T lymphocytes associated lymphocytes 8

AUR Adenylate uridylate rich

NF-kB Nuclear factor kappa B

cDNA Complentary desoxyribonucleic acid

TGF- $\beta \quad$ Transforming growth factor $\beta$

IL-17R Interleukin-17 receptor

SEFIR Similar expression to fibroblast growth factor genes and IL-17R

TRAF Tumor necrosing factor receptor associated factor

MAPK Mitogen-activated protein kinase

ERK Extracellular signal-regulated kinase

p38 p38 kinase

JNK c-Jun N-terminal kinase

IKKi I kappa B kinase

TBK1 TANK binding kinase 1

mRNA Messenger ribonucleic acid

HuR Human antigen $R$

ASF/SF2 Serine/arginine rich splicing factor 2

TAK1 Transforming growth factor $\beta$ activated kinase 1

SMURF2 Smad ubiquitination regulatory factor

DAZAP2 Deleted in azoospermia associated 2

GM-CSF Granulocyte-macrophage colony-stimulating factor

STAT Signal transducer and activator of transcription

TYK Tyrosine kinase

ROR $\gamma \quad$ RAR-related orphan receptor gamma

ITRC Innate tissue resident cells

ILC3 type 3 innate lymphoid cells

CCR Chemokine receptor

SBR Scarf Bloom and Richardson

BrdU Bromodeoxyuridine

siRNA Small interfering ribonucleic acid

c-RAF RAF proto-oncogene serine/threonine-protein kinase

STAT Signal transducer and activator of transcription

TPL2 Tumor progression locus 2

TIL Tumor-infiltrating lymphocytes

MMP Matrix metalloproteinase

SDF-1 Stromal derived factor 1

M-CSF Macrophage colony-stimulating factor

SCID Severe combined immunodeficiency

CM Conditioned medium

MEC Mammary epithelial cell

MDSC Myeloid-derived suppressor cells

LMWCE Low molecular weight cyclin E

MEKK MAPK/extracellular signal-regulated kinase kinase

PrC Prostate cancer

\section{References}

1. Ferlay, J.; Colombet, M.; Soerjomataram, I.; Dyba, T.; Randi, G.; Bettio, M.; Gavin, A.; Visser, O.; Bray, F. Cancer incidence and mortality patterns in europe: Estimates for 40 countries and 25 major cancers in 2018. Eur. J. Cancer 2018, 103, 356-387. [CrossRef] 
2. Senkus, E.; Kyriakides, S.; Ohno, S.; Penault-Llorca, F.; Poortmans, P.; Rutgers, E.; Zackrisson, S.; Cardoso, F.; Committee, E.G. Primary breast cancer: Esmo clinical practice guidelines for diagnosis, treatment and follow-up. Ann. Oncol. Off. J. Eur. Soc. Med. Oncol./ESMO 2015, 26 (Suppl. 5), v8-v30. [CrossRef] [PubMed]

3. Altundag, K. Have all triple-negative breast cancer patients worse breast cancer-specific survival? Breast 2017, 36, 102. [CrossRef] [PubMed]

4. Feng, Y.; Spezia, M.; Huang, S.; Yuan, C.; Zeng, Z.; Zhang, L.; Ji, X.; Liu, W.; Huang, B.; Luo, W.; et al. Breast cancer development and progression: Risk factors, cancer stem cells, signaling pathways, genomics, and molecular pathogenesis. Genes Dis. 2018, 5, 77-106. [CrossRef]

5. Lal, S.; McCart Reed, A.E.; de Luca, X.M.; Simpson, P.T. Molecular signatures in breast cancer. Methods 2017, 131, 135-146. [CrossRef] [PubMed]

6. Sorlie, T.; Perou, C.M.; Tibshirani, R.; Aas, T.; Geisler, S.; Johnsen, H.; Hastie, T.; Eisen, M.B.; van de Rijn, M.; Jeffrey, S.S.; et al. Gene expression patterns of breast carcinomas distinguish tumor subclasses with clinical implications. Proc. Natl. Acad. Sci. USA 2001, 98, 10869-10874. [CrossRef]

7. Perou, C.M.; Sorlie, T.; Eisen, M.B.; van de Rijn, M.; Jeffrey, S.S.; Rees, C.A.; Pollack, J.R.; Ross, D.T.; Johnsen, H.; Akslen, L.A.; et al. Molecular portraits of human breast tumours. Nature 2000, 406, 747-752. [CrossRef] [PubMed]

8. Russnes, H.G.; Lingjaerde, O.C.; Borresen-Dale, A.L.; Caldas, C. Breast cancer molecular stratification: From intrinsic subtypes to integrative clusters. Am. J. Pathol. 2017, 187, 2152-2162. [CrossRef]

9. Cardoso, F.; Senkus, E.; Costa, A.; Papadopoulos, E.; Aapro, M.; Andre, F.; Harbeck, N.; Aguilar Lopez, B.; Barrios, C.H.; Bergh, J.; et al. 4th eso-esmo international consensus guidelines for advanced breast cancer (abc 4)dagger. Ann. Oncol. Off. J. Eur. Soc. Med. Oncol./ESMO 2018, 29, 1634-1657. [CrossRef] [PubMed]

10. Ballinger, T.J.; Meier, J.B.; Jansen, V.M. Current landscape of targeted therapies for hormone-receptor positive, her2 negative metastatic breast cancer. Front. Oncol. 2018, 8, 308. [CrossRef]

11. Westphal, T.; Gampenrieder, S.P.; Rinnerthaler, G.; Greil, R. Cure in metastatic breast cancer. Memo 2018, 11, 172-179. [CrossRef] [PubMed]

12. Eng, L.G.; Dawood, S.; Sopik, V.; Haaland, B.; Tan, P.S.; Bhoo-Pathy, N.; Warner, E.; Iqbal, J.; Narod, S.A.; Dent, R. Ten-year survival in women with primary stage iv breast cancer. Breast Cancer Res. Treat. 2016, 160, 145-152. [CrossRef] [PubMed]

13. Dirix, L.Y.; Takacs, I.; Jerusalem, G.; Nikolinakos, P.; Arkenau, H.T.; Forero-Torres, A.; Boccia, R.; Lippman, M.E.; Somer, R.; Smakal, M.; et al. Avelumab, an anti-pd-11 antibody, in patients with locally advanced or metastatic breast cancer: A phase $1 b$ javelin solid tumor study. Breast Cancer Res. Treat. 2018, 167, 671-686. [CrossRef] [PubMed]

14. Wein, L.; Luen, S.J.; Savas, P.; Salgado, R.; Loi, S. Checkpoint blockade in the treatment of breast cancer: Current status and future directions. Br. J. Cancer 2018, 119, 4-11. [CrossRef] [PubMed]

15. Hui, L.; Chen, Y. Tumor microenvironment: Sanctuary of the devil. Cancer Lett. 2015, 368, 7-13. [CrossRef] [PubMed]

16. Genova, C.; Rossi, G.; Rijavec, E.; Biello, F.; Barletta, G.; Tagliamento, M.; Grossi, F. Releasing the brake: Safety profile of immune check-point inhibitors in non-small cell lung cancer. Expert Opin. Drug Saf. 2017, 16, 573-585. [CrossRef] [PubMed]

17. Ascierto, P.A.; McArthur, G.A. Checkpoint inhibitors in melanoma and early phase development in solid tumors: What's the future? J. Transl. Med. 2017, 15, 173. [CrossRef] [PubMed]

18. Samadi, P.; Saki, S.; Dermani, F.K.; Pourjafar, M.; Saidijam, M. Emerging ways to treat breast cancer: Will promises be met? Cell. Oncol. (Dordr.) 2018, 41, 605-621. [CrossRef]

19. Balkwill, F.; Mantovani, A. Inflammation and cancer: Back to virchow? Lancet 2001, 357, 539-545. [CrossRef]

20. Diakos, C.I.; Charles, K.A.; McMillan, D.C.; Clarke, S.J. Cancer-related inflammation and treatment effectiveness. Lancet Oncol. 2014, 15, e493-e503. [CrossRef]

21. DeNardo, D.G.; Coussens, L.M. Inflammation and breast cancer. Balancing immune response: Crosstalk between adaptive and innate immune cells during breast cancer progression. Breast Cancer Res. 2007, 9, 212. [CrossRef] [PubMed]

22. Setrerrahmane, S.; Xu, H. Tumor-related interleukins: Old validated targets for new anti-cancer drug development. Mol. Cancer 2017, 16, 153. [CrossRef] [PubMed]

23. Sloot, Y.J.E.; Smit, J.W.; Joosten, L.A.B.; Netea-Maier, R.T. Insights into the role of il-32 in cancer. Semin. Immunol. 2018. [CrossRef] [PubMed] 
24. Holen, I.; Lefley, D.V.; Francis, S.E.; Rennicks, S.; Bradbury, S.; Coleman, R.E.; Ottewell, P. Il-1 drives breast cancer growth and bone metastasis in vivo. Oncotarget 2016, 7, 75571-75584. [CrossRef] [PubMed]

25. Heo, T.H.; Wahler, J.; Suh, N. Potential therapeutic implications of il-6/il-6r/gp130-targeting agents in breast cancer. Oncotarget 2016, 7, 15460-15473. [CrossRef] [PubMed]

26. Amatya, N.; Garg, A.V.; Gaffen, S.L. Il-17 signaling: The yin and the yang. Trends Immunol. 2017, 38, 310-322. [CrossRef]

27. Song, Y.; Yang, J.M. Role of interleukin (il)-17 and t-helper (th)17 cells in cancer. Biochem. Biophys. Res. Commun. 2017, 493, 1-8. [CrossRef]

28. Rouvier, E.; Luciani, M.F.; Mattei, M.G.; Denizot, F.; Golstein, P. Ctla-8, cloned from an activated t cell, bearing au-rich messenger rna instability sequences, and homologous to a herpesvirus saimiri gene. J. Immunol. 1993, 150, 5445-5456.

29. Yao, Z.; Painter, S.L.; Fanslow, W.C.; Ulrich, D.; Macduff, B.M.; Spriggs, M.K.; Armitage, R.J. Human il-17: A novel cytokine derived from t cells. J. Immunol. 1995, 155, 5483-5486.

30. Gaffen, S.L. Life before seventeen: Cloning of the il-17 receptor. J. Immunol. 2011, 187, 4389-4391. [CrossRef]

31. Isailovic, N.; Daigo, K.; Mantovani, A.; Selmi, C. Interleukin-17 and innate immunity in infections and chronic inflammation. J. Autoimmun. 2015, 60, 1-11. [CrossRef] [PubMed]

32. Fabre, J.; Giustiniani, J.; Garbar, C.; Antonicelli, F.; Merrouche, Y.; Bensussan, A.; Bagot, M.; Al-Dacak, R. Targeting the tumor microenvironment: The protumor effects of il-17 related to cancer type. Int. J. Mol. Sci. 2016, 17, 1433. [CrossRef] [PubMed]

33. Fabre, J.; Giustiniani, J.; Antonicelli, F.; Merrouche, Y.; Bagot, M.; Bensussan, A. A focus on il-17 targeting treatments in psoriasis. J. Dermatol. Res. 2016, 2, 1-5. [CrossRef]

34. Giusti, D.; Le Jan, S.; Gatouillat, G.; Bernard, P.; Pham, B.N.; Antonicelli, F. Biomarkers related to bullous pemphigoid activity and outcome. Exp. Dermatol. 2017, 26, 1240-1247. [CrossRef]

35. Kim, G.; Khanal, P.; Lim, S.C.; Yun, H.J.; Ahn, S.G.; Ki, S.H.; Choi, H.S. Interleukin-17 induces ap-1 activity and cellular transformation via upregulation of tumor progression locus 2 activity. Carcinogenesis 2013, 34, 341-350. [CrossRef] [PubMed]

36. Le Jan, S.; Plee, J.; Vallerand, D.; Dupont, A.; Delanez, E.; Durlach, A.; Jackson, P.L.; Edwin Blalock, J.; Bernard, P.; Antonicelli, F. Innate immune cell-produced il-17 sustains inflammation in bullous pemphigoid. J. Investig. Dermatol. 2014, 134, 2908-2917. [CrossRef] [PubMed]

37. Plee, J.; Le Jan, S.; Giustiniani, J.; Barbe, C.; Joly, P.; Bedane, C.; Vabres, P.; Truchetet, F.; Aubin, F.; Antonicelli, F.; et al. Integrating longitudinal serum il-17 and il-23 follow-up, along with autoantibodies variation, contributes to predict bullous pemphigoid outcome. Sci. Rep. 2015, 5, 18001. [CrossRef]

38. Fan, Z.; Yang, J.; Yang, C.; Guo, X. Il-17: A promising therapeutic target for atherosclerosis. Int. J. Cardiol. 2016, 202, 930-931. [CrossRef]

39. Fossiez, F.; Djossou, O.; Chomarat, P.; Flores-Romo, L.; Ait-Yahia, S.; Maat, C.; Pin, J.J.; Garrone, P.; Garcia, E.; Saeland, S.; et al. T cell interleukin-17 induces stromal cells to produce proinflammatory and hematopoietic cytokines. J. Exp. Med. 1996, 183, 2593-2603. [CrossRef]

40. Hymowitz, S.G.; Filvaroff, E.H.; Yin, J.P.; Lee, J.; Cai, L.; Risser, P.; Maruoka, M.; Mao, W.; Foster, J.; Kelley, R.F.; et al. Il-17s adopt a cystine knot fold: Structure and activity of a novel cytokine, il-17f, and implications for receptor binding. EMBO J. 2001, 20, 5332-5341. [CrossRef]

41. McDonald, N.Q.; Hendrickson, W.A. A structural superfamily of growth factors containing a cystine knot motif. Cell 1993, 73, 421-424. [CrossRef]

42. Moseley, T.A.; Haudenschild, D.R.; Rose, L.; Reddi, A.H. Interleukin-17 family and il-17 receptors. Cytokine Growth Factor Rev. 2003, 14, 155-174. [CrossRef]

43. Chang, S.H.; Dong, C. A novel heterodimeric cytokine consisting of il-17 and il-17f regulates inflammatory responses. Cell Res. 2007, 17, 435-440. [CrossRef] [PubMed]

44. Wright, J.F.; Guo, Y.; Quazi, A.; Luxenberg, D.P.; Bennett, F.; Ross, J.F.; Qiu, Y.; Whitters, M.J.; Tomkinson, K.N.; Dunussi-Joannopoulos, K.; et al. Identification of an interleukin 17f/17a heterodimer in activated human cd4+ t cells. J. Biol. Chem. 2007, 282, 13447-13455. [CrossRef] [PubMed]

45. Huang, X.D.; Zhang, H.; He, M.X. Comparative and evolutionary analysis of the interleukin 17 gene family in invertebrates. PLoS ONE 2015, 10, e0132802. [CrossRef] [PubMed]

46. Kolls, J.K.; Linden, A. Interleukin-17 family members and inflammation. Immunity 2004, 21, 467-476. [CrossRef] [PubMed] 
47. Iwakura, Y.; Ishigame, H.; Saijo, S.; Nakae, S. Functional specialization of interleukin-17 family members. Immunity 2011, 34, 149-162. [CrossRef]

48. Bie, Q.; Jin, C.; Zhang, B.; Dong, H. Il-17b: A new area of study in the il-17 family. Mol. Immunol. 2017, 90, 50-56. [CrossRef]

49. Zhang, B.; Liu, C.; Qian, W.; Han, Y.; Li, X.; Deng, J. Structure of the unique sefir domain from human interleukin 17 receptor a reveals a composite ligand-binding site containing a conserved alpha-helix for act1 binding and il-17 signaling. Acta Crystallogr. D Biol. Crystallogr. 2014, 70, 1476-1483. [CrossRef]

50. Patel, D.D.; Lee, D.M.; Kolbinger, F.; Antoni, C. Effect of il-17a blockade with secukinumab in autoimmune diseases. Ann. Rheum. Dis. 2013, 72 (Suppl. 2) (Suppl. 2), ii116-ii123. [CrossRef]

51. Wright, J.F.; Bennett, F.; Li, B.; Brooks, J.; Luxenberg, D.P.; Whitters, M.J.; Tomkinson, K.N.; Fitz, L.J.; Wolfman, N.M.; Collins, M.; et al. The human il-17f/il-17a heterodimeric cytokine signals through the il-17ra/il-17rc receptor complex. J. Immunol. 2008, 181, 2799-2805. [CrossRef] [PubMed]

52. Zrioual, S.; Toh, M.L.; Tournadre, A.; Zhou, Y.; Cazalis, M.A.; Pachot, A.; Miossec, V.; Miossec, P. Il-17ra and il-17rc receptors are essential for il-17a-induced elr+ cxc chemokine expression in synoviocytes and are overexpressed in rheumatoid blood. J. Immunol. 2008, 180, 655-663. [CrossRef] [PubMed]

53. Kuestner, R.E.; Taft, D.W.; Haran, A.; Brandt, C.S.; Brender, T.; Lum, K.; Harder, B.; Okada, S.; Ostrander, C.D.; Kreindler, J.L.; et al. Identification of the il-17 receptor related molecule il-17rc as the receptor for il-17f. J. Immunol. 2007, 179, 5462-5473. [CrossRef] [PubMed]

54. Monin, L.; Gaffen, S.L. Interleukin 17 family cytokines: Signaling mechanisms, biological activities, and therapeutic implications. Cold Spring Harb. Perspect. Biol. 2018, 10. [CrossRef] [PubMed]

55. Mosmann, T.R.; Cherwinski, H.; Bond, M.W.; Giedlin, M.A.; Coffman, R.L. Two types of murine helper $t$ cell clone. I. Definition according to profiles of lymphokine activities and secreted proteins. J. Immunol. 1986, 136, 2348-2357.

56. Aarvak, T.; Chabaud, M.; Miossec, P.; Natvig, J.B. Il-17 is produced by some proinflammatory th1/th0 cells but not by th2 cells. J. Immunol. 1999, 162, 1246-1251.

57. Steinman, L. A brief history of $t(h) 17$, the first major revision in the $t(h) 1 / t(h) 2$ hypothesis of $t$ cell-mediated tissue damage. Nat. Med. 2007, 13, 139-145. [CrossRef]

58. Park, H.; Li, Z.; Yang, X.O.; Chang, S.H.; Nurieva, R.; Wang, Y.H.; Wang, Y.; Hood, L.; Zhu, Z.; Tian, Q.; et al. A distinct lineage of $\mathrm{cd} 4 \mathrm{t}$ cells regulates tissue inflammation by producing interleukin 17. Nat. Immunol. 2005, 6, 1133-1141. [CrossRef]

59. Korn, T.; Oukka, M.; Kuchroo, V.; Bettelli, E. Th17 cells: Effector t cells with inflammatory properties. Semin. Immunol. 2007, 19, 362-371. [CrossRef]

60. Liang, S.C.; Tan, X.Y.; Luxenberg, D.P.; Karim, R.; Dunussi-Joannopoulos, K.; Collins, M.; Fouser, L.A. Interleukin (il)-22 and il-17 are coexpressed by th17 cells and cooperatively enhance expression of antimicrobial peptides. J. Exp. Med. 2006, 203, 2271-2279. [CrossRef]

61. Nurieva, R.; Yang, X.O.; Martinez, G.; Zhang, Y.; Panopoulos, A.D.; Ma, L.; Schluns, K.; Tian, Q.; Watowich, S.S.; Jetten, A.M.; et al. Essential autocrine regulation by il-21 in the generation of inflammatory $\mathrm{t}$ cells. Nature 2007, 448, 480-483. [CrossRef] [PubMed]

62. Smith, J.A. The bench-to-bedside story of il-17 and the therapeutic efficacy of its targeting in spondyloarthritis. Curr. Rheumatol. Rep. 2016, 18, 33. [CrossRef] [PubMed]

63. Veldhoen, M.; Hocking, R.J.; Atkins, C.J.; Locksley, R.M.; Stockinger, B. Tgfbeta in the context of an inflammatory cytokine milieu supports de novo differentiation of il-17-producing t cells. Immunity 2006, 24, 179-189. [CrossRef] [PubMed]

64. Bystrom, J.; Taher, T.E.; Muhyaddin, M.S.; Clanchy, F.I.; Mangat, P.; Jawad, A.S.; Williams, R.O.; Mageed, R.A. Harnessing the therapeutic potential of th17 cells. Med. Inflamm. 2015, 2015, 205156. [CrossRef] [PubMed]

65. Ciofani, M.; Madar, A.; Galan, C.; Sellars, M.; Mace, K.; Pauli, F.; Agarwal, A.; Huang, W.; Parkhurst, C.N.; Muratet, M.; et al. A validated regulatory network for th17 cell specification. Cell 2012, 151, 289-303. [CrossRef] [PubMed]

66. Huber, M.; Heink, S.; Pagenstecher, A.; Reinhard, K.; Ritter, J.; Visekruna, A.; Guralnik, A.; Bollig, N.; Jeltsch, K.; Heinemann, C.; et al. Il-17a secretion by cd8+ $\mathrm{t}$ cells supports th17-mediated autoimmune encephalomyelitis. J. Clin. Investig. 2013, 123, 247-260. [CrossRef] [PubMed]

67. Kronenberg, M. Toward an understanding of nkt cell biology: Progress and paradoxes. Annu. Rev. Immunol. 2005, 23, 877-900. [CrossRef] [PubMed] 
68. Marks, B.R.; Nowyhed, H.N.; Choi, J.Y.; Poholek, A.C.; Odegard, J.M.; Flavell, R.A.; Craft, J. Thymic self-reactivity selects natural interleukin 17-producing $\mathrm{t}$ cells that can regulate peripheral inflammation. Nat. Immunol. 2009, 10, 1125-1132. [CrossRef]

69. Cua, D.J.; Sherlock, J.; Chen, Y.; Murphy, C.A.; Joyce, B.; Seymour, B.; Lucian, L.; To, W.; Kwan, S.; Churakova, T.; et al. Interleukin-23 rather than interleukin-12 is the critical cytokine for autoimmune inflammation of the brain. Nature 2003, 421, 744-748. [CrossRef]

70. Noordenbos, T.; Blijdorp, I.; Chen, S.; Stap, J.; Mul, E.; Canete, J.D.; Lubberts, E.; Yeremenko, N.; Baeten, D. Human mast cells capture, store, and release bioactive, exogenous il-17a. J. Leukoc. Biol. 2016, 100, 453-462. [CrossRef] [PubMed]

71. Lin, A.M.; Rubin, C.J.; Khandpur, R.; Wang, J.Y.; Riblett, M.; Yalavarthi, S.; Villanueva, E.C.; Shah, P.; Kaplan, M.J.; Bruce, A.T. Mast cells and neutrophils release il-17 through extracellular trap formation in psoriasis. J. Immunol. 2011, 187, 490-500. [CrossRef] [PubMed]

72. Wang, K.; Karin, M. The il-23 to il-17 cascade inflammation-related cancers. Clin. Exp. Rheumatol. 2015, 33, S87-S90. [PubMed]

73. Morita, H.; Arae, K.; Unno, H.; Toyama, S.; Motomura, K.; Matsuda, A.; Suto, H.; Okumura, K.; Sudo, K.; Takahashi, T.; et al. Il-25 and il-33 contribute to development of eosinophilic airway inflammation in epicutaneously antigen-sensitized mice. PLOS ONE 2015, 10, e0134226. [CrossRef] [PubMed]

74. Wang, Y.H.; Angkasekwinai, P.; Lu, N.; Voo, K.S.; Arima, K.; Hanabuchi, S.; Hippe, A.; Corrigan, C.J.; Dong, C.; Homey, B.; et al. Il-25 augments type 2 immune responses by enhancing the expansion and functions of tslp-dc-activated th2 memory cells. J. Exp. Med. 2007, 204, 1837-1847. [CrossRef] [PubMed]

75. Manni, M.L.; Robinson, K.M.; Alcorn, J.F. A tale of two cytokines: Il-17 and il-22 in asthma and infection. Expert Rev. Respir. Med. 2014, 8, 25-42. [CrossRef] [PubMed]

76. Corrigan, C.J.; Wang, W.; Meng, Q.; Fang, C.; Eid, G.; Caballero, M.R.; Lv, Z.; An, Y.; Wang, Y.H.; Liu, Y.J.; et al. Allergen-induced expression of il-25 and il-25 receptor in atopic asthmatic airways and late-phase cutaneous responses. J. Allergy Clin. Immunol. 2011, 128, 116-124. [CrossRef]

77. Kleinschek, M.A.; Owyang, A.M.; Joyce-Shaikh, B.; Langrish, C.L.; Chen, Y.; Gorman, D.M.; Blumenschein, W.M.; McClanahan, T.; Brombacher, F.; Hurst, S.D.; et al. Il-25 regulates th17 function in autoimmune inflammation. J. Exp. Med. 2007, 204, 161-170. [CrossRef]

78. Ramirez-Carrozzi, V.; Sambandam, A.; Luis, E.; Lin, Z.; Jeet, S.; Lesch, J.; Hackney, J.; Kim, J.; Zhou, M.; Lai, J.; et al. Il-17c regulates the innate immune function of epithelial cells in an autocrine manner. Nat. Immunol. 2011, 12, 1159-1166. [CrossRef]

79. Hwang, S.Y.; Kim, H.Y. Expression of il-17 homologs and their receptors in the synovial cells of rheumatoid arthritis patients. Mol. Cells 2005, 19, 180-184.

80. Li, H.; Chen, J.; Huang, A.; Stinson, J.; Heldens, S.; Foster, J.; Dowd, P.; Gurney, A.L.; Wood, W.I. Cloning and characterization of il-17b and il-17c, two new members of the il-17 cytokine family. Proc. Natl. Acad. Sci. USA 2000, 97, 773-778. [CrossRef]

81. Starnes, T.; Broxmeyer, H.E.; Robertson, M.J.; Hromas, R. Cutting edge: Il-17d, a novel member of the il-17 family, stimulates cytokine production and inhibits hemopoiesis. J. Immunol. 2002, 169, 642-646. [CrossRef] [PubMed]

82. Salvator Fabre, J.A. The multifaceted immune system. MOJ Immunol. 2016, 3. [CrossRef]

83. Bonnet, M.C.; Bagot, M.; Bensussan, A. Monoclonal antibodies targeting il-17a or its receptor in psoriasis: A new therapeutic approach? Med. Sci. (Paris) 2012, 28, 1035-1037. [CrossRef] [PubMed]

84. Van Uden, D.J.; van Laarhoven, H.W.; Westenberg, A.H.; de Wilt, J.H.; Blanken-Peeters, C.F. Inflammatory breast cancer: An overview. Crit. Rev. Oncol./Hematol. 2015, 93, 116-126. [CrossRef] [PubMed]

85. Zhu, X.; Mulcahy, L.A.; Mohammed, R.A.; Lee, A.H.; Franks, H.A.; Kilpatrick, L.; Yilmazer, A.; Paish, E.C.; Ellis, I.O.; Patel, P.M.; et al. Il-17 expression by breast-cancer-associated macrophages: Il-17 promotes invasiveness of breast cancer cell lines. Breast Cancer Res. 2008, 10, R95. [CrossRef]

86. Cochaud, S.; Giustiniani, J.; Thomas, C.; Laprevotte, E.; Garbar, C.; Savoye, A.M.; Cure, H.; Mascaux, C.; Alberici, G.; Bonnefoy, N.; et al. Il-17a is produced by breast cancer tils and promotes chemoresistance and proliferation through erk1/2. Sci. Rep. 2013, 3, 3456. [CrossRef] [PubMed]

87. Du, J.W.; Xu, K.Y.; Fang, L.Y.; Qi, X.L. Interleukin-17, produced by lymphocytes, promotes tumor growth and angiogenesis in a mouse model of breast cancer. Mol. Med. Rep. 2012, 6, 1099-1102. [CrossRef] [PubMed] 
88. Eiro, N.; Fernandez-Garcia, B.; Gonzalez, L.O.; Vizoso, F.J. Cytokines related to mmp-11 expression by inflammatory cells and breast cancer metastasis. Oncoimmunology 2013, 2, e24010. [CrossRef]

89. Merrouche, Y.; Fabre, J.; Cure, H.; Garbar, C.; Fuselier, C.; Bastid, J.; Antonicelli, F.; Al-Daccak, R.; Bensussan, A.; Giustiniani, J. Il-17e synergizes with egf and confers in vitro resistance to egfr-targeted therapies in tnbc cells. Oncotarget 2016, 7, 53350-53361. [CrossRef]

90. Nam, J.S.; Terabe, M.; Kang, M.J.; Chae, H.; Voong, N.; Yang, Y.A.; Laurence, A.; Michalowska, A.; Mamura, M.; Lonning, S.; et al. Transforming growth factor beta subverts the immune system into directly promoting tumor growth through interleukin-17. Cancer Res. 2008, 68, 3915-3923. [CrossRef]

91. Roy, L.D.; Ghosh, S.; Pathangey, L.B.; Tinder, T.L.; Gruber, H.E.; Mukherjee, P. Collagen induced arthritis increases secondary metastasis in mmtv-pyv mt mouse model of mammary cancer. BMC Cancer 2011, 11, 365. [CrossRef] [PubMed]

92. Roy, L.D.; Sahraei, M.; Schettini, J.L.; Gruber, H.E.; Besmer, D.M.; Mukherjee, P. Systemic neutralization of il-17a significantly reduces breast cancer associated metastasis in arthritic mice by reducing cxcl12/sdf-1 expression in the metastatic niches. BMC Cancer 2014, 14, 225. [CrossRef] [PubMed]

93. Mombelli, S.; Cochaud, S.; Merrouche, Y.; Garbar, C.; Antonicelli, F.; Laprevotte, E.; Alberici, G.; Bonnefoy, N.; Eliaou, J.F.; Bastid, J.; et al. Il-17a and its homologs il-25/il-17e recruit the c-raf/s6 kinase pathway and the generation of pro-oncogenic lmw-e in breast cancer cells. Sci. Rep. 2015, 5, 11874. [CrossRef] [PubMed]

94. Laprevotte, E.; Cochaud, S.; du Manoir, S.; Lapierre, M.; Dejou, C.; Philippe, M.; Giustiniani, J.; Frewer, K.A.; Sanders, A.J.; Jiang, W.G.; et al. The il-17b-il-17 receptor b pathway promotes resistance to paclitaxel in breast tumors through activation of the erk1/2 pathway. Oncotarget 2017, 8, 113360-113372. [CrossRef] [PubMed]

95. Keyomarsi, K.; Tucker, S.L.; Buchholz, T.A.; Callister, M.; Ding, Y.; Hortobagyi, G.N.; Bedrosian, I.; Knickerbocker, C.; Toyofuku, W.; Lowe, M.; et al. Cyclin e and survival in patients with breast cancer. The N. Engl. J. Med. 2002, 347, 1566-1575. [CrossRef] [PubMed]

96. Bonner, J.A.; Maihle, N.J.; Folven, B.R.; Christianson, T.J.; Spain, K. The interaction of epidermal growth factor and radiation in human head and neck squamous cell carcinoma cell lines with vastly different radiosensitivities. Int. J. Radiat. Oncol. Biol. Phys. 1994, 29, 243-247. [CrossRef]

97. Huang, C.K.; Yang, C.Y.; Jeng, Y.M.; Chen, C.L.; Wu, H.H.; Chang, Y.C.; Ma, C.; Kuo, W.H.; Chang, K.J.; Shew, J.Y.; et al. Autocrine/paracrine mechanism of interleukin- $17 \mathrm{~b}$ receptor promotes breast tumorigenesis through nf-kappab-mediated antiapoptotic pathway. Oncogene 2014, 33, 2968-2977. [CrossRef]

98. Coffelt, S.B.; Kersten, K.; Doornebal, C.W.; Weiden, J.; Vrijland, K.; Hau, C.S.; Verstegen, N.J.; Ciampricotti, M.; Hawinkels, L.J.; Jonkers, J.; et al. Il-17-producing gammadelta t cells and neutrophils conspire to promote breast cancer metastasis. Nature 2015, 522, 345-348. [CrossRef]

99. Jiang, Z.; Chen, J.; Du, X.; Cheng, H.; Wang, X.; Dong, C. Il-25 blockade inhibits metastasis in breast cancer. Protein Cell 2017, 8, 191-201. [CrossRef]

100. Eiro, N.; Gonzalez, L.; Gonzalez, L.O.; Fernandez-Garcia, B.; Lamelas, M.L.; Marin, L.; Gonzalez-Reyes, S.; del Casar, J.M.; Vizoso, F.J. Relationship between the inflammatory molecular profile of breast carcinomas and distant metastasis development. PLoS ONE 2012, 7, e49047. [CrossRef]

101. Benatar, T.; Cao, M.Y.; Lee, Y.; Lightfoot, J.; Feng, N.; Gu, X.; Lee, V.; Jin, H.; Wang, M.; Wright, J.A.; et al. Il-17e, a proinflammatory cytokine, has antitumor efficacy against several tumor types in vivo. Cancer Immunol. Immunother. 2010, 59, 805-817. [CrossRef] [PubMed]

102. Furuta, S.; Jeng, Y.M.; Zhou, L.; Huang, L.; Kuhn, I.; Bissell, M.J.; Lee, W.H. Il-25 causes apoptosis of il-25r-expressing breast cancer cells without toxicity to nonmalignant cells. Sci. Transl. Med. 2011, 3, 78 ra31. [CrossRef] [PubMed]

103. Ma, M.; Huang, W.; Kong, D. Il-17 inhibits the accumulation of myeloid-derived suppressor cells in breast cancer via activating stat3. Int. Immunopharmacol. 2018, 59, 148-156. [CrossRef] [PubMed]

104. Nam, J.S.; Terabe, M.; Mamura, M.; Kang, M.J.; Chae, H.; Stuelten, C.; Kohn, E.; Tang, B.; Sabzevari, H.; Anver, M.R.; et al. An anti-transforming growth factor beta antibody suppresses metastasis via cooperative effects on multiple cell compartments. Cancer Res. 2008, 68, 3835-3843. [CrossRef] [PubMed]

105. Yang, B.; Kang, H.; Fung, A.; Zhao, H.; Wang, T.; Ma, D. The role of interleukin 17 in tumour proliferation, angiogenesis, and metastasis. Mediat. Inflamm. 2014, 2014, 623759. [CrossRef] [PubMed]

106. Qian, X.; Chen, H.; Wu, X.; Hu, L.; Huang, Q.; Jin, Y. Interleukin-17 acts as double-edged sword in anti-tumor immunity and tumorigenesis. Cytokine 2015, 89, 34-44. [CrossRef] 
107. Honorati, M.C.; Neri, S.; Cattini, L.; Facchini, A. Il-17 enhances the susceptibility of u-2 os osteosarcoma cells to nk cell lysis. Clin. Exp. Immunol. 2003, 133, 344-349. [CrossRef]

108. O'Sullivan, T.; Saddawi-Konefka, R.; Gross, E.; Tran, M.; Mayfield, S.P.; Ikeda, H.; Bui, J.D. Interleukin-17d mediates tumor rejection through recruitment of natural killer cells. Cell Rep. 2014, 7, 989-998. [CrossRef]

109. Parajuli, P.; Mittal, S. Role of il-17 in glioma progression. J. Spine Neurosurg. 2013, (Suppl. 1), S1-S4. [CrossRef]

110. Wu, F.; Xu, J.; Huang, Q.; Han, J.; Duan, L.; Fan, J.; Lv, Z.; Guo, M.; Hu, G.; Chen, L.; et al. The role of interleukin-17 in lung cancer. Mediat. Inflamm. 2016, 2016, 8494079. [CrossRef]

111. Gu, K.; Li, M.M.; Shen, J.; Liu, F.; Cao, J.Y.; Jin, S.; Yu, Y. Interleukin-17-induced emt promotes lung cancer cell migration and invasion via nf-kappab/zeb1 signal pathway. Am. J. Cancer Res. 2015, 5, 1169-1179. [PubMed]

112. Feng, M.; Wang, Y.; Chen, K.; Bian, Z.; Jinfang, W.; Gao, Q. Il-17a promotes the migration and invasiveness of cervical cancer cells by coordinately activating mmps expression via the $\mathrm{p} 38 / \mathrm{nf}$-kappab signal pathway. PLoS ONE 2014, 9, e108502. [CrossRef] [PubMed]

113. Tartour, E.; Fossiez, F.; Joyeux, I.; Galinha, A.; Gey, A.; Claret, E.; Sastre-Garau, X.; Couturier, J.; Mosseri, V.; Vives, V.; et al. Interleukin 17, a t-cell-derived cytokine, promotes tumorigenicity of human cervical tumors in nude mice. Cancer Res. 1999, 59, 3698-3704. [PubMed]

114. Pan, B.; Shen, J.; Cao, J.; Zhou, Y.; Shang, L.; Jin, S.; Cao, S.; Che, D.; Liu, F.; Yu, Y. Interleukin-17 promotes angiogenesis by stimulating vegf production of cancer cells via the stat3/giv signaling pathway in non-small-cell lung cancer. Sci. Rep. 2015, 5, 16053. [CrossRef]

115. Proverbs-Singh, T.; Feldman, J.L.; Morris, M.J.; Autio, K.A.; Traina, T.A. Targeting the androgen receptor in prostate and breast cancer: Several new agents in development. Endocr. Relat. Cancer 2015, 22, R87-R106. [CrossRef] [PubMed]

116. Zhang, Q.; Liu, S.; Ge, D.; Zhang, Q.; Xue, Y.; Xiong, Z.; Abdel-Mageed, A.B.; Myers, L.; Hill, S.M.; Rowan, B.G.; et al. Interleukin-17 promotes formation and growth of prostate adenocarcinoma in mouse models. Cancer Res. 2012, 72, 2589-2599. [CrossRef] [PubMed]

117. Zhang, Q.; Liu, S.; Parajuli, K.R.; Zhang, W.; Zhang, K.; Mo, Z.; Liu, J.; Chen, Z.; Yang, S.; Wang, A.R.; et al. Interleukin-17 promotes prostate cancer via mmp7-induced epithelial-to-mesenchymal transition. Oncogene 2016, 36, 687-699. [CrossRef] [PubMed]

118. Chen, C.; Zhang, Q.; Liu, S.; Parajuli, K.R.; Qu, Y.; Mei, J.; Chen, Z.; Zhang, H.; Khismatullin, D.B.; You, Z. Il-17 and insulin/igf1 enhance adhesion of prostate cancer cells to vascular endothelial cells through cd44-vcam-1 interaction. Prostate 2015, 75, 883-895. [CrossRef] [PubMed]

119. Welte, T.; Zhang, X.H. Interleukin-17 could promote breast cancer progression at several stages of the disease. Mediat. Inflamm. 2015, 2015, 804347. [CrossRef]

120. Loget, J.; Plee, J.; Antonicelli, F.; Bernard, P. A successful treatment with ustekinumab in a case of relapsing bullous pemphigoid associated with psoriasis. J. Eur. Acad. Dermatol. Venereol. 2017, 31, e228-e230. [CrossRef]

(C) 2018 by the authors. Licensee MDPI, Basel, Switzerland. This article is an open access article distributed under the terms and conditions of the Creative Commons Attribution (CC BY) license (http:// creativecommons.org/licenses/by/4.0/). 